\title{
Claiming the forest: inclusions and exclusions under Indonesia's 'new' forest policies on customary forests
}

\author{
Rodd Myers \\ Global Environmental Justice Group School of International Development University of East \\ Anglia Norwich Research Park, Norwich, NR4 7TJ, UK roderick.myers99@alumni.imperial.ac.uk \\ rodd.myers@uea.ac.uk \\ Dian Intarini \\ University of Twente, Enschede, NL \\ d.intarini@gmail.com \\ Martua Thomas Sirait \\ The Samdhana Institute, Jakarta, ID \\ martua@samdhana.org
}

\begin{abstract}
Ahmad Maryudi*
Faculty of Forestry, Universitas Gadjah Mada Bulaksumur, Yogyakarta, Indonesia 55281 ahmad_maryudi@ugm.ac.id maryudi76@yahoo.com*Corresponding author

Pre-publication version. Please cite publication version

Myers, R, Intarini, D, Sirait, MT, Maryudi, A (2017). Claiming the forest: Inclusions and exclusions under Indonesia's 'new' forest policies on customary forests. Land Use Policy (22) 205-213.

Published version available at

http://dx.doi.org/10.1016/j.landusepol.2017.04.039
\end{abstract}




\begin{abstract}
The hopes of customary communities in Indonesia have recently been bolstered by Constitutional Court assurances that they have the right to control customary forest. There are, however, several obstacles to making successful claims, and there are also many situations in which forest users and customary land claimants do not stand to benefit from the recent rulings. This policy review analyses the court decisions, politics around their implementation, and considerations of types of land claimants who are excluded from the current process. We highlight groups of forest and ex-forestland users that are excluded from benefiting from the Constitutional Court decisions and are adversely affected by land use change and re-designation of land. These groups include those with claims over land in conservation areas, allocated to concessionaires for resource extraction, on land already issued to them through forest management rights, and those whose land has already been removed from the State forest land.
\end{abstract}

Highlights:

- Contestations around claims by customary groups on forest areas in Indonesia have been rejuvenated by 2011 and 2012 Constitutional Court decisions.

- There remains significant confusion around how to apply the laws, however both State and customary community rights groups are actively advancing their preparations

- The Constitutional Court decisions are specific to 'customary communities' with claims over State forest land.

- Communities with claims over gazetted national parks, land issued for forestry concessions, land removed from the State forest, and migrants remain without legal basis for claiming forest land.

Keywords:

Indonesia, customary, forest, exclusion, law 


\section{Introduction}

Customary forest users in Indonesia have long made claims over forestland defined and controlled by the State. Indigenous rights organisations estimate that approximately 40 million hectares of Indonesian State forestland should be under customary control (AMAN 2013). In 2011 and 2012, the Constitutional Court ruled with claimants ${ }^{1}$ on three landmark rulings (collectively called the 'Constitutional Court decisions' in this paper) that challenged some provisions in the 1999 Forestry Law among others. The first decision was that the rights of all communities must be respected and protected in the implementation of the State's control over State forests (hutan negara). This ruling will be referred to in this article as MK 34 (MK34/PUU-IX/2011). The second was MK 35 (MK35/PUU-X/2012) in which hutan adat (customary forests) were recognised as a new category of hutan hak (titled forests), ${ }^{2}$ the second of two categories of forests listed in Article 6 of the 1999 Forestry Law. Hutan adat, under this decision, should be considered outside State forestland. ${ }^{3}$ Along with State forestland, titled forests should be recognised as one type of forestland tenure. The third, MK 45 (MK45/PUU-IX/2011) changed the meaning of 'state forest zone' (kawasan hutan) to include only areas that have been vetted through a gazettement process. This meant that the process of determining forest boundaries, which includes the consultation of customary and local forest users, must be undertaken before forestland can be placed under the purview of the Ministry of Environment and Forestry (MoEF). ${ }^{4}$ These three decisions were supported by a broader adat movement and Indigenous rights organisations (especially AMAN [Aliansi Masyarakat Adat Nusantara]) (Rachman and Siscawati 2016). The decisions are significant for the confirmation of existing laws. The laws themselves are not 'new,' but the Constitutional Court decisions inject new political and legal clout to customary claims over forests.

By October 2016, AMAN, the Indonesian Network for Participatory Mapping (Jaringan Kerja Pemetaan Partisipatif [JKPP]), and the Ancestral Domain Registration Agency (Badan Registrasi Wilayah Adat [BRWA]) had mapped 932 individual customary forests covering 7.3 million hectares of customary territory, most of which overlaps with State forestland. Only seven of these areas have been verified by BRWA, an association led by customary communities. Two of these areas were issued 'certificates' by BRWA, which aims to position these areas for formal claims to the State. ${ }^{5}$ In addition, $34 \%$ of all identified areas are in West

\footnotetext{
${ }^{1}$ Claimants were Aliansi Masyarakat Adat Nusantara (AMAN) and customary leaders on MK 35 and private and formal leaders on MK 34 and 45.

${ }^{2}$ The term 'titled forests' includes both individual and collective titles and is literally translated as "rights forests," but we use translation that is consistent with the official translation of the law, which is 'title forests,' which is used by several authors (e.g., Sahide and Giessen 2015). Other authors refer to this as 'privately owned forests' (e.g., Indrarto et al. 2012; Fujiwara et al. 2011), which we also consider appropriate.

${ }^{3}$ The question of whether hutan adat remain inside or should be considered outside State forests remains a subject of debate, but the current interpretation by the MoEF is that they should remain inside State forests.

${ }^{4}$ Prior to October 2014, this was the Ministry of Forestry (MoF). We use both ministry names depending on the context.

${ }^{5}$ The State does not officially recognise BRWA certificates and has its own process called the IP4T (Inventarisasi Penguasaan, Pemilikan, Penggunaan dan Pemanfaatan Tanah/Inventory Control, Ownership, Use, and Utilisation of Land), which is jointly managed by the Ministry of Environment and Forestry (MoEF), the Ministry of Internal Affairs (Kementerian Dalam Negeri), and the National Land Agency (Kementerian Agraria dan Tata Ruang/Badan Pertanahan Nasional). Only the result of the IP4T is sufficient for the State to release the land from the Forest Zone. The District Head (Bupati) issues a Peraturan Daerah (District Law), which would formally authorise hutan adat within the District's powers, but the authority to release the land is
} 
Kalimantan, $14 \%$ of the areas are in North Sumatera, $9 \%$ of the areas are in South Sulawesi, and the rest of the areas are distributed among other provinces (BRWA 2016a; BRWA 2016b). The first nine customary forest claims were recognised formally by the State on December 30, 2016, covering 13,122 hectares (Fanani 2017).

In this review, we discuss the events leading up to and following the Constitutional Court decisions. Our focus is on who, among the claimants of the forests, stands to benefit from these decisions and associated regulations and who, among marginalised forest users, do not. We argue that while the Constitutional Court decisions are an important step forward for customary forest users, many groups of forest users (among them the most disadvantaged) are excluded from accessing these avenues to benefit from forests and forest resources. At the end of this article, we make several recommendations for the claims process for both hutan adat and the forgotten communities that are invisible under the Constitutional Court rulings. Indonesian forest use and designation terminologies are overlapping and often confusing. We clarify them here and bracket the Indonesian term for clarity. The focus of this article is on hutan adat, which means 'customary forests' but we maintain the Indonesian term because of the embedded meanings of 'adat,' which we discuss briefly. We use hutan adat to mean the legal definition of customary forests as described in MK 35, as opposed to regionally designated customary forests at the district (kabupaten) or provincial levels. We refer to the forest management regimes of village forests (hutan desa), community forests (hutan kemasyarakatan), and people's plantations (hutan tanaman rakyat) collectively as 'social forestry' and individually by their Indonesian names to avoid ambiguity. The entire forest zone (kawasan hutan) is under the responsibility of the MoEF, but the State has direct control over State forests (hutan negara) and only influences the scope of activities that can be undertaken in titled forests (hutan hak). The forest zone is designated for specific uses, broadly including production forests (hutan produksi), protection forests (hutan lindung), and conservation forests (hutan konservasi). ${ }^{6}$

This article is based on the independent research initiatives of the authors. Therefore, we provide examples from several regions of Indonesia that involve diverse data collection and analysis methods to strengthen our review. Our aim is to consolidate some of the key findings of these studies and come to a parsimonious set of insights and recommendations that culminate in a policy review. Consequently, we do not purport to provide new empirical evidence in this paper. We base our analysis on previous data and works both published and unpublished. We specifically focus on customary forests in Indonesia, but we are aware of the greater forces at play that are tied in with global capitalist notions of conservation and natural resource management.

Before explaining the processes leading up to the Constitutional Court decisions and the results of these decisions, we explore the forest tenure security in Indonesia. We look at the basis for claim-making among communities and what the Constitutional Court decisions mean for land claims both within and outside of State forestland. We then analyse who stands to benefit from these decisions and who does not. We consider this an important and unaddressed aspect of the Constitutional Court rulings. Our intent is not to diminish the

within the auspices of IP4T. At the time of writing, data on the progress of IP4T were not available, and there were no known cases of recognition of hutan adat by the IP4T.

${ }^{6}$ There are more nuanced breakdowns and variations of these categories, but this simplified categorisation will suffice for this discussion. 
importance of the Constitutional Court decisions, as we believe they are an unprecedented step forward for forest user rights in Indonesia. Our focus is on forest and forest resource users who fall outside the contested definitions of communities that are entitled to benefit from the Constitutional Court decisions and subsequent 'new' laws. Finally, we make several recommendations after a brief discussion.

\section{Forest tenure security in Indonesia}

Indonesia's Forestry Law (number 41/1999) stipulates that the State designates the forest zone (kawasan hutan) to affirm the designation of permanent forests (hutan tetap). The process of gazetting the forest zone includes designating specific land as an indicative forest estate, ground-truthing and verifying the land (including considering community land claims), and finally establishing delineation (penataan batas) until the enactment (penetapan) of such land as a definitive forest estate. MK 45 confirms that the legality of zoning of forestland will be determined by this entire process.

Indonesia's forest zone (especially State forests) is central to national forestry planning and operates under 'scientific' forestry principles (Peluso 1992). Under this system, the State is the key actor that ensures the efficient control and management of forest resources (Peluso and Vandergeest 2001). This system was inherited from the Dutch colonial government, which established territoriality in Java through a policy of Domain Declaration. Upon independence, the State implemented the Javanese forest management system in Forest Law 5/67 in the entire archipelago (Barr et al. 2006; Maryudi 2015b). The policy stated that any unowned land was the State's domain. Forests were often considered as 'empty' or 'wasteland' and were the first territories grabbed by the Dutch (and subsequently the State) for forestry and other uses, particularly when debates about customary claims had not been resolved (Peluso, Afiff, and Rachman 2008). ${ }^{7}$

The Indonesian national government adopts the concept of the State's right of control over forests (hak menguasai negara) in which the State is not the forest owner as assumed in the Domain Declarations, but it is a representative of the Indonesian people charged with controlling the forests by applying its statutory authority to allocate, regulate, and determine legal relations amongst citizens with regard to the forests. In practice, the State performs as the owner by controlling and limiting people's access to forests and making agreements on forest use (ijin) and forestland exchange (tukar-menukar), including agreements on forestland that has not yet been gazetted.

Adat claimants, on the other hand, use the basis of custom (often defined differently and overly complex to summarise in this review) to make their claims. We explore the differences of framing land tenure claims here.

\subsection{Legal basis for land tenure}

Forest Law 41/1999 defines both State and privately titled forests within the State forest zone, although the latter rarely existed prior to hutan adat. State forests, as discussed, are located on land without any formal land rights, while titled forests are located on titled land, which could include private ownership, use rights, or right for commercial cultivation rights as regulated by Basic Agrarian Law (BAL) number 5 of 1960. The enactment of the

\footnotetext{
${ }^{7}$ This logic also extends to transmigration programmes in which the State considered outer islands as empty and requiring to develop (Taylor 2003).
} 
BAL was intended to bridge the gap between 'Western' law and customary law by providing registration of individual land rights, while also continuing to recognise customary land law concepts and institutions (Wright 2011). Prior to May 16, 2013, the day the Constitutional Court ruled on MK 35, customary forests were assumed to be part of State forests. Collective tenures were treated as weak rights of usufruct (Colchester 2002). According to the Constitutional Court rulings, this assumption was not aligned with Indonesia's Constitution, which recognises the existence of customary users and their rights. The Constitutional Court corrected the understanding of the MoEF in the Forestry Law by stating that hutan adat are part of titled forests, but they are still within the State forest zone (i.e., still considered 'forests' by the MoEF). The MoEF has the power to grant licenses for utilising national forests to private companies or local communities and to directly manage conservation forests, but have no such powers on titled forestland.

Even before the Constitutional Court decisions, there were already several ways that local forest users could gain management rights over State forests. These schemes were not directly changed by the Constitutional Court decisions. Village forests (hutan desa [HD]) licences are granted to village institutions, and community forests (hutan kemasyarakatan $[\mathrm{HKm}]$ ) and People's Planted Forest (hutan tanaman rakyat [HTR]) licences are issued to community groups, such as producer associations or co-operatives. The HTR scheme aims to encourage local people to engage in more financial-oriented forest practices to accelerate the development of timber plantations, while the HKm and HD schemes usually encourage smaller scale community-based livelihoods activities. The HTR scheme was principally driven by the slow progress of large-scale/industrial plantation forests (Hutan Tanaman Industri). Further partnerships can be developed between communities and State-owned enterprises for the management of private forest concessions. Table 1 shows the similarities and differences among these schemes.

Table 1: Arrangements for $\mathrm{HKm}, \mathrm{HD}$, and HTR social forestry schemes

\begin{tabular}{|l|l|l|l|}
\hline & HKm & HD & HTR \\
\hline Scope & $\begin{array}{l}\text { Group or cooperative } \\
\text { use rights over: } \\
\text {-Timber from planted } \\
\text { trees (only in Production } \\
\begin{array}{l}\text { Forests) } \\
\text {-Non-timber forest } \\
\text { products } \\
\text {-Environmental services }\end{array}\end{array}$ & $\begin{array}{l}\text { Village management } \\
\text { rights over: } \\
\text {-Timber from both } \\
\text { natural and planted } \\
\text { forests (in Production } \\
\text { Forest areas) } \\
\text {-Non-timber forest } \\
\text { products } \\
\text {-Environmental services }\end{array}$ & $\begin{array}{l}\text { Individual or cooperative } \\
\text { use rights in Production } \\
\text { Forests under three different } \\
\text { models: } \\
\text {-Independent, established at } \\
\text { own initiative and cost } \\
\text {-Partnership or joint venture } \\
\text { with plantation company } \\
\text {-Led by a company under an } \\
\text { outgrower scheme }\end{array}$ \\
\hline Conditionality & $\begin{array}{l}\text { Use subject to separate } \\
\text { business license; not } \\
\text { alienable and cannot be } \\
\text { collateralised }\end{array}$ & $\begin{array}{l}\text { Use subject to separate } \\
\text { business license }\end{array}$ & $\begin{array}{l}\text { Use rights granted at outset; } \\
\text { not alienable and only } \\
\text { planted trees can use be } \\
\text { used for collateral }\end{array}$ \\
\hline Duration & 35 years & 35 years & 60 years \\
\hline
\end{tabular}

Adapted from Royo and Wells (2012) 
Although there are several instruments legally available to communities to access forest resources, the impact of these models has been limited so far. By the end of 2014, the MoEF granted less than 1 million hectares of State forests for local communities. This was below their 2.5-million-hectare target. In production forests, approximately 97\% was granted for corporations, and the remaining 3\% was used for social forestry (Direktorat Jenderal Planologi Kehutanan 2014).

The MoEF excludes hutan adat from forest estates. Ministerial Regulation 62/2013 (Peraturan Menteri Kehutanan No. P.62/Menhut-II/2013), for instance, clearly states that customary territories located in forest zones that have been verified will be released from the forest zone. This is not in line with MK 35 and Law 41/1999, which stipulate that there are the two types of forests within the forest zone already discussed, but the MoEF understands its responsibility for only State forests within the forest zone. Despite this, customary users are bolstered by the Constitutional Court decisions. In the process of setting up their claims through participatory mapping and collecting, any evidence that they anticipate will be deemed acceptable proof of customary use by the MoEF.

\subsection{Adat in forest and land law}

Law 5 of 1960 (i.e., the BAL) recognises adat (customary or custom) law as coexisting with national law; however, few regulations have been introduced that relate directly to adat (Wright 2011). We note Ministry of Agriculture rule Permen Agraria 5/1999 as an exception in which customary land rights are recognised in non-forestland. Article 5 of the BAL reads as follows:

The Agrarian law applies to the land, water and air space is customary law, to the extent that it is not contrary to national interest and the State, which is based on national unity, Indonesian socialism and the regulations contained in this Law and other regulations, and to any elements that rely on religious principles.

Forestry Law 41/1999 effectively negated customary land tenure security for those with customary claims over forests by regulating that all forestland not owned under private land rights be directly controlled by the State. Within this, only claimants meeting the following criteria would be considered as having customary forests: (1) the society is organised as a distinguishable community; (2) there are existing structures and institutional arrangements; (3) there are clear territories and boundaries based on customary law; (4) customary law and customary judiciaries still exist; (5) societies still gather forest products to fulfil their daily needs; and (6) the claim has the support of the district government. These principles have been in place for 15 years, and yet Constitutional Court challenges were required to lead to hutan adat being realised in the country.

The government often cited the BAL as a constraint to issuing hutan adat, in which it is stated that the allocation of land should not contradict national interests (ContrerasHermosilla and Fay 2005). Before the Constitutional Court decisions, Moeliono (2002) and Moniaga $(1993 ; 2007)$ already questioned in what ways the role of national law and practices would erode adat traditions and serve to integrate local communities politically, economically, and socially into the nation-state. 


\subsection{Gazettement of forestland}

Only a small portion of the forest zone had been gazetted before 2009. The Ministry of Forestry (MoF) stated that only 13.8 million hectares (11.29\%) had been gazetted as national forestland (Kementerian Kehutanan 2013). Since the Constitutional Court decisions were made, the MoEF has put considerable efforts into gazetting forest estates. As Figure 1 shows, by the end of 2014, the MoEF had gazetted 76.5 million hectares of State forests or approximately $63 \%$ of the 121 million hectares of the State forest areas. This figure was up from 13.8 million hectares by the end of 2011 (unchanged since 2009). Almost 62 million hectares in 821 forest areas (units) were established in 2014 alone.

While this recent accelerated effort has increased the area of 'legal' State forestland, it has further strained the contestations over the legitimacy of the process of defining land tenure security and control over Indonesia's forests. Indigenous rights groups consider this influx a preventative action that will ensure continued State control over forests. A representative of the MoEF who we interviewed anonymously confirmed this as the Ministry's strategy. In the meantime, the MoEF has been engaged in consultations with a wide range of stakeholders to set the parameters for the operationalisation of hutan adat. While that process had been going on for 3 years, the Ministry quickly removed forest inventories that are eligible to be claimed (see Figure 1). ${ }^{8}$

The Ministry requires the consent of community members to gazette forests, but the legitimacy of consent by community authorities is often questioned in such cases (Myers et al. 2016; see also Setiawan et al. 2016; Prabowo et al. 2017). A representative of a customary community organisation we interviewed suggested that the Ministry is gazetting forestland where there are minimal conflicts or movement from customary claimants. He also suggested that local people lack awareness of new provisions for hutan adat and, therefore, are not aware that by consenting to MoEF gazettement, they are making hutan adat claims more challenging in the future. Our respondent also mentioned that the MoEF generally explains social forestry initiatives to communities, but does not always explain that hutan adat are a form of titled forest (hutan hak), not right-to-use (hak pakai) forests. The Ministry often couples forest management arrangements with incentives, such as training and inputs and rubber seedlings, but no such provisions have been extended within hutan adat arrangements so far.

An MoEF official who we interviewed was even more blunt in saying that community consultations were bypassed altogether, and forests were being gazetted based on digital maps with local ground-truthing based on the advice of local forest authorities only. The official referred to this as a "time bomb waiting to go off."

\footnotetext{
${ }^{8}$ The targets for forest gazettement are laid out in the national planning document Rencana Pembangunan Jangka Menengah Nasional 2015-2019.
} 
Figure 1: Progress of Forest Area Gazettement 2011-2014

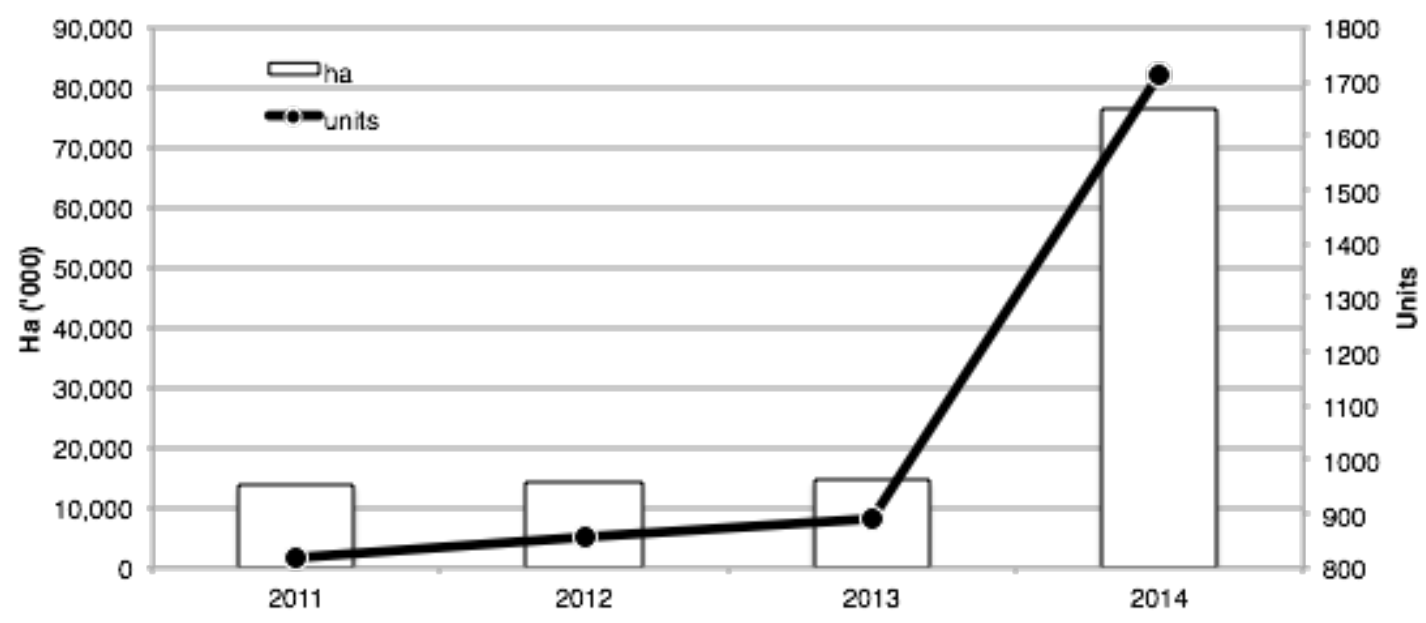

Data source: Direktorat Jenderal Planologi Kehutanan/Directorate General of Forestry Planning in Kementerian Lingkungan Hidup dan Kehutanan (2015)

History shows us other examples of contrary regulations and laws, including the transmigration programme in which local inhabitants lost their rights to land to governmentsponsored migrant workers (Elmhirst 2011) and the issuance of licences to forestry, plantation, and mining companies on adat lands without consultation, let alone implementation of free, prior, informed consent (FPIC) (Barr 2006; Colchester et al. 2006). Contestations of these contrasts are voiced by community groups, nongovernmental organisations (NGOs), customary rights organisations, different levels of government, and companies. We deliberately take a broader focus than customary users alone, as many of the contestations revealed in this review are not from customary users, but local communities more generally. We also acknowledge that the term adat is increasingly politically charged and provides the illusion that it somehow represents all customary communities in Indonesia, when actual claims and interests of these communities can be themselves divergent and conflicting (Henley 2007; Bettinger, Fisher, and Miles 2014).

\subsection{Framing of land tenure claims}

Claims are strengthened and legitimised by customary users wielding adat as a political tool (Henley and Davidson 2007). Claimants make claims to customary and statutory institutions with the aspirations of obtaining not simply usage rights, but ownership rights over land to which they assert they are entitled through use, cultural identity, and historical statutory rights. The claimants' legitimacy is found in the institutions that recognise their claims, including non-State institutions (e.g., customary institutions). In turn, these institutions seek recognition for their claims through State authorities (cf. Lund 2010; Sikor and Stahl 2011). Some of these claims against the State have been ongoing for generations (cf. Myers and Muhajir 2015).

Here, we explore several ways in which villagers claim forestland and what kinds of rights they embed in their claims. State, international, and supranational conventions addressing the recognition of rights provide robust support for claims framed by customary rights - defined by law, custom, and convention. However, customary claims are not reliant on these external institutions for their own legitimacy. Approaching rights to the forests can be seen from a human rights perspective, such as land rights as property rights, cultural rights for customary communities, gender equality rights, rights for adequate housing, and food security rights 
(Gilbert 2014). However, rights to forests viewed as a bundle of rights are more broad. This bundle of rights includes the rights to sell forest products, hold local governments accountable, secure legal tenure, derive economic benefits, and exercise individual and collective rights. Sikor et al. (2011) explain that forest tenure is the right to determine who holds and uses forestland and resources, for how long, and under what conditions. From the perspective of customary land tenure, customary users are "rightful owners and managers of all forests because they have ancestral claims that predate the arrival of the state" (Sunderlin 2011,21).

Customary land claims in Indonesia are often championed by customary leaders or community activists empowered by leaders. This is a basis of claim-making found by others in parts of Africa (Neumann 1998; Watts 2004) and Indonesia specifically (Li 2007; Bakker and Moniaga 2010). The common bases of the claims include a distinct community, a customary leadership structure, defined boundaries, customary roles in place, and a customary leader (or leaders) that will ensure management of the land. This roughly aligns with the 1999 conditions for making claims on forestland in Indonesia; however, where the State frames these conditions under land (or property) conditions, adat claims are made on custom. Nevertheless, customary communities may shift their framing to align with concerns of the State. Watts and Bohle (1993) write about rights claims and food security, which serve as another basis for claim-making (more generally related to livelihoods). Some of the cases that we have researched in Indonesia have made claims to manage property on an environmental basis. For example, encroaching oil palm plantations could threaten community access to water or create flooding. Therefore, claims have been successfully made in Kalimantan for community forests so that the forestland will not be used by oil palm plantations (Myers et al. 2016). Hence, although the framings of land tenure claims may have different origins, they may converge with the logics of the State in order to be heard among State authorities.

\section{Who stands to benefit and who does not?}

Exactly which communities are considered 'customary' remains the interpretation of the State. Although the preliminary guidance was established in Forestry Law 41/1999 (see section 2), the implementation of the law remains malleable. Therefore, exactly 'who benefits' remains to be seen since these criteria were not applied prior to the Constitutional Court decisions. Community-based forest users who have no ability to make claims based on the Constitutional Court decisions are more clear, and we highlight some key contexts in which exclusion occurs here.

We identify five situations in which community-based forest users do not stand to benefit from the Constitutional Court decisions. This analysis is not to minimise the Constitutional Court decisions, but it is to suggest that the decisions do not confirm the rights of all types of forest claimants, as we acknowledge they are not intended to do. We simply highlight that while MK 35 strictly applies to customary communities within the forest zone, MK 45 applies to all forest users within the forest zone. Therefore, there are specific groups of both customary and non-customary forest users that do not stand to benefit from the rulings, indicating that further policies could be warranted using similar principles to that which are embodied in the Constitutional Court decisions. First, customary users with claims over land exclusively outside the forest zone cannot benefit from the rulings. Second, forest users with claims over gazetted conservation forest areas, such as national parks, may not be able to 
benefit from the rulings. Third, customary claims over land that has already been converted to non-forestland (Area Pengunaan Lain [APL]) are not able to make claims supported by the rulings. Fourth, forest users with statutory management rights may find their claims challenging. Fifth, transmigrant and forced migrant communities with claims over forestland would not be able to make claims on a customary basis. Here, we examine all five of these situations.

\subsection{Customary claims outside State forestland}

Between 2011 and 2014, 1.6 million hectares of forestland were converted to agricultural use (Kementerian Lingkungan Hidup dan Kehutanan 2015), usually for conversion to industrial activities. In Kalimantan, these activities are largely oil palm (cf. Setiawan et al. 2016). Because the authority over these lands was previously vested in the MoF, with no obligation to consult customary users on the change of the status of the land (nor for the appropriation of land into State forestland in the first place), there is little evidence of regard for customary claims in these land use conversions. Since $1999,{ }^{9}$ Indonesia has required that industrial activities include an environmental impact assessment (AMDAL), which includes the consultation of communities, but does not specify the quality of consultation (Myers and Ardiansyah 2014). The AMDAL is initiated after land has already been converted to nonforestland (cf. Setiawan et al. 2016). There are many documented cases of AMDALs gone wrong by either bypassing community consultation or applying sufficient pressure or incentives that community leaders endorse the AMDAL in service of their own interests (Colchester 2006; Myers and Ardiansyah 2014). Therefore, these communities are trebly disadvantaged. First, their lands were appropriated by the State to become State forests. Then, their land was issued to companies for industrial logging. Finally, former forestland may be converted for industrial agricultural use (such as oil palm) on which they have no basis for claim-making at a national level because their customary land is not included in the Constitutional Court rulings since it was removed from the forest zone. At subnational levels, some districts have established processes for customary land claims (see Pahlevi 2015). Further, the National Commission on Human Rights (Komnas HAM) (2016) made a recommendation that communities whose land was removed from State forests for oil palm plantations have their land and rights restored and that the State has the responsibility to correct past human rights violations.

\subsection{Customary claims on conservation forest}

There are different interpretations of whether or not MK 35 applies to national parks and conservation areas. These areas are sometimes understood as regulated under Law 5/1990 on the conservation of biodiversity and ecosystems rather than Forestry Law 41/1999 (Magdalena and Supriadi 2014), making them a special case for hutan adat. Others understand that the Constitutional Court decisions apply to all State forests, including national parks and protected forests. Hutan adat claims in conservation areas are particularly complicated because of the application of both laws (Magdalena and Supriadi 2014; The Samdhana Institute and Rights and Resources 2016). Law 5/1990 applies specifically to conservation and biodiversity and states that designated zones within conservation areas prohibit human activity (inti and rimba). These areas, argues the MoEF, would not be

\footnotetext{
${ }^{9}$ The AMDAL was introduced in PP No.27/1999 Analisis Mengenai Dampak Lingkungan (Environmental Impact Analysis).
} 
available for hutan adat claims. (We assume this means if they are gazetted, which we discuss in more detail later.) Other zones within conservation areas, known as livelihood zones (pemanfaatan), seem to be less clear candidates for hutan adat claims.

The MoEF's first policy response to the Constitutional Court decisions is detailed in Permenhut P 62/2013. It was highly critical of the implications of the implementations of the ruling for Indonesia's conservation areas and national parks. The MoEF cited the concern that the release of conservation areas to hutan adat would put Indonesia's forests in jeopardy and result in the loss of all conservation areas in Indonesia. The MoEF's recommendation is that hutan adat remain within State forestland and, therefore, still under the control of the Ministry.

Not all conservation areas have completed the exercise of gazettement. Such areas are especially contested as to whether or not MK 35 applies. However, even the gazetted areas can be controversial. The establishment of national parks, for example, sometimes included some form of participation of local forest users. The levels of participation vary widely, and sometimes the gazettement of national parks has happened against the wishes of local users. In West Kalimantan, there are contestations against the borders of Bukit Baka Bukit Raya National Park. Village leaders agreed to the establishment of the park without consulting the broader community (Myers and Muhajir 2015). This community has submitted its claim for hutan adat, including a portion that overlaps with the national park. Communities around Lore Lindu National Park in Central Sulawesi were not given the option of the gazettement of the park (Myers 2015). Both of these cases have overlapping customary claims over national park land and involve incomplete information issued to forest users at the time of gazettement, which is also found in other land use change negotiations in Indonesia (cf. Myers et al. 2016).

\subsection{Claims on concession forests}

Production forests ${ }^{10}$ comprise 56.5 million hectares of land in Indonesia (Kementerian Lingkungan Hidup dan Kehutanan 2015). There is already a case in which hutan adat are claimed over a pulpwood concession (Foresthints.news 2017). In another case in Tumbang Titi, Ketapang, West Kalimantan, conflict arose among villagers within several villages around a corporate forest concession established in 2011. There are overlapping claims among individuals, families, and villages as customary land users and the concession holders (Prabowo et al. 2017). According to local claimants, the central government was aware of the contested land tenure prior to issuing the licence to the company. Despite this knowledge, according to plantation firm insiders, the government has preferred to refrain from mediation and leave it to the communities and the companies to sort out these issues amongst themselves, a condition also found elsewhere in Indonesia (cf. Myers et al. 2016; Maryudi et al. 2016; Maryudi and Krott 2012).

In 2016, the Ministry of Agrarian and Spatial Planning issued a regulation that would enable communal rights (hak komunal) on estate crop land (Permen Agraria 10/2016). This could afford a similar right to claimants (customary and non-customary) on land that has been released from State forests (e.g., oil palm plantations), but claimants on forestland under commercial concessions remain challenged to exercise their constitutional claims.

\footnotetext{
${ }^{10}$ Including production forests and limited production forests.
} 


\subsection{Forest users with statutory management rights in the forest}

Restrictions on the customary access of forest people have occurred due to decentralisation during precolonial times, postcolonial times, and post-independence for several reasons (Barr 2006; Arnscheidt 2009; Safitri 2010). Since then, ultimate power over forestland has been in the hands of the State. Conflict has emerged as customary rights and villagers' access to forestland are neglected (Safitri 2010). However, since the BAL of 1960, the marginalisation of adat societies has been due mainly to the allocation of forest concessions to forest companies, mining companies, and oil plant plantation firms by the State. NGOs and customary community organisations have made repeated calls for agrarian reform and created several land rights movements, claiming the recognition and affirmation of the fundamental right to lands to little avail.

Some communities with customary claims in State forests have been awarded forest management rights by subnational officials on behalf of the MoEF (see section 3.1). Depending on the district, these management rights take the form of community or village forests (hutan kemasyarakatan and hutan desa, respectively). Management rights can be allocated to production and protection forests. In both cases, communities gain management rights under strict government monitoring; however, ownership rights are not transferred to communities. $^{11}$

Some communities reject any benefits from the State for fear that acceptance of any benefits would serve to legitimise the rights of the State to make land use decisions on customary land. Others make agreements with the State, signalling acceptance that the State has the authority to issue land use permits on customary land (cf. Lund 2011). The question, then, is how does acceptance of this authority affect customary rights land use claims?

Forest management schemes issue management rights over forests in accordance with 'scientific forestry principles,' negating claims of customary ownership and control (FKKM and HUMA 2012). The MoEF's regulations on social forestry have been used by the State as evidence of its commitment to empower forest-dependent people and as a strategy to slow deforestation. However, this commitment is supported by insufficient resources for effective implementation. The MoEF's strategic plan for social forestry targets 12.7 million hectares under social forestry by 2019 under the new government. The previous government target in 2010-2014 was 500,000 hectares. By June 2012, only 83,401 hectares had been established as hutan desa (Kementerian Kehutanan 2013), and by the end of 2014, only 318,024 hectares of hutan desa had been established (Kompas 2015). The reasons for the delays in issuing community management rights are too many to go into detail here (see Intarini et al. 2014). Community-managed forestry regulations fail to address the fundamental issue of land tenure security because they only transfer usage rights (not ownership rights) to communities. These rights are fragile at best. They are highly conditional on the approved plans and monitoring by district and provincial level departments of forestry (Maryudi 2015a). Therefore, communities lack control over access and are only empowered to maintain the ability to benefit from the forest within the plans approved by the government. For instance, if a community forest management group wishes to access timber resources from the forest under its management, its statutory standing to do so is contingent on the following conditions: (a) the area of forest being designated is one in which timber extraction is permissible (i.e., not a

\footnotetext{
${ }^{11}$ See MoF regulation P. 49/Menhut-II/2008 for details.
} 
protected forest area); (b) timber harvesting is included in its government-approved plan; and (c) approved permits exist for the planned timber extraction activities. The activities that are permissible within community-management permits are still controlled by the MoEF and its regional counterparts.

According to our research initiatives, the advantages of forest management schemes to communities tend to be the protection of land from encroaching extractive industries, including primarily oil palm, logging, mining, and other industrial plantations (Myers et al. 2016). Thus far, communities holding hutan desa, hutan kemasyarakatan, and hutan tanaman rakyat permits are not explicitly exempt from making hutan adat claims. In many ways, they are in a position of advantage, learning from the management rights processes. For example, in Beringin Rayo, Ketapang, West Kalimantan, a village regulation on hutan desa is in place. A forest management institution has been created, and a village team mapped out forest territories and boundaries designated for hutan desa (including commons and individual ownership). Further, the village regulation is passed through the district government and then to the legal bureau and a series of review boards, often taking years to complete. Many of these experiences prepare the community to meet State requirements for hutan adat claims.

The costs, however, are the legitimisation of the State's control over land (cf. Sikor and Lund 2009). As communities grasp at strategies to protect their forests against extractive industries, they find themselves making deals for short-term permission to use their own land, conceding that the State has the authority to set the conditions under which the forestland can be used. This logic directly conflicts with the Constitutional Court rulings that clearly state that hutan adat should be considered as outside State forests.

A second cost to these schemes could be the definition of the boundaries of forestland under the management and future control of communities. The boundaries of hutan desa, hutan kemasyarakatan, and hutan tanaman rakyat are negotiated between forest users and the district, provincial, or central governments granting the permit. Forest users typically propose an area, and the MoEF considers the proposal, including the extent to which the land is "clear and clean' of contesting claims. If customary communities claim a more expansive area than that which was negotiated for the management rights (or overlap the area with management rights), claims may be made more difficult because smaller territories have already been agreed upon for forest management. Claims made outside of these areas could be dismissed by the government in claims for hutan adat. In Desa Beringin Rayo, hutan desa was established in 2011 in a protected forest. According to villagers, part of this hutan desa is in what they consider to be hutan adat. An NGO helped them to acquire hutan desa management rights, and they have not claimed any hutan adat to the State. According to interviews with local NGOs and government officials, if the community would want to convert hutan desa management rights to become hutan adat, this could be considered only if (a) the hutan desa boundaries are within the hutan adat territory claim; (b) the district government recognises the hutan adat claim; and (c) the community is no longer holding hutan desa management rights. The Constitutional Court decision on claiming hutan adat as titled forests was made a year after the award of hutan desa management rights to the village. However, the community was not aware that hutan adat could be claimed, and local respondents suggested that they would not have applied for hutan desa if hutan adat were an option. They are concerned about the problematic conversion from management to ownership rights. This situation, according to local NGOs and community leaders, has become problematic for any future claims for hutan adat. 


\subsection{Transmigrant and forced migrant claims over forestland}

Indonesia has had various transmigration programmes since colonial times, responsible for moving millions of Indonesians. The Dutch relocated communities so that the communities could be better monitored and more easily 'modernised,' which included conversion to Christianity (Li 2007) at a local scale, and so that the population pressures on Java within the colony could be reduced (Fearnside 1997). After independence, and especially under the New Order Soeharto era (1967-1998), transmigration programmes were intended to increase the productivity of underutilised land by offering it to small holders willing to work the land ( $\mathrm{Li}$ 2011). Transmigration also aimed to reduce ethnic contrasts among the islands so that citizens would identify themselves as Indonesian rather than by minority ethnic groups (Fearnside 1997). Another motivation for the continuation of the program was to move people out of areas designated for forest conservation (Elmhirst 2011). Post-New Order, the program continued but pivoted its proposition to be a source of cheap labour to investors willing to invest in outlying islands. These investments included commercial crops, such as oil palm (Li 2011), which required labour, often on former State forests.

The focus of this analysis is on migrants who were translocated during the New Order to forest or forest-adjacent areas. Some of these communities have been established for almost 50 years. These groups are distinct from voluntary migrants in that, in addition to being forcefully relocated, they comprise the majority of the population in several localities, often with a cohesive ethnic identity. Each family was issued land that they were expected to farm (see IPAC 2013 and Fearnside 1997). The scheme was criticised for its impacts on the environment since many of the newly established villages were in forest areas, which were perceived by the government to be less contested by customary land claims (Fearnside 1997). This led to deforestation for the creation of settlements and the opening of farm land. Another problem with the scheme, which was only experienced later, was a lack of consideration for population growth. Many villages composed of transmigrants experience severe pressures on land. The original two hectares per family that were issued (at least after 1996, with amounts less clear or standardised before that) have been divided among two and now three generations. This leaves insufficient land for household agriculture, and expansion is not always permitted by the State, especially when the settlements border forestland. Therefore, many villagers have turned to adjacent forestland for their daily needs. In a Sumbawa village visited by the lead author of this paper, the community was forced to migrate to make way for a national park in Lombok 20 years ago. According to community members, the forest was cleared 25 years ago and not replanted. Upland from the village, the bare soil turned to scrubland and resulted in frequent flooding in the new village. Seeing an opportunity both to use land and to reforest the forestland with trees, villagers restocked the forest using their own labour and fruit tree seedlings. According to accounts of villagers, the fruit trees provided stable food supplies, access to fuelwood, and protection from flooding. However, they are in constant conflict with the forest police, who arrest any villager in the designated forest area carrying so much as a machete.

According to a new regulation created jointly by the Ministry of Internal Affairs, MoEF, Public Works, and the National Land Agency (79/2014; PB.3/Menhut-11/2014; 17/PRT/M/2014; 8/SKB/X/2014), transmigrants for more than 20 years have the "right to land" (Article 8(1)), yet it is not clear what this right entails. One of the conditions to make a hutan adat claim is that there are customary institutions in place for the management of the forest. "We have no customary law," claimed a community leader in Sumbawa. "We are 
transmigrants." So tied is custom to land that even the villagers themselves have become disconnected with their customary laws as they were separated from their land. The village can make no claim to customary land since their homeland is in a national park where they no longer live. Like the other forest users in this section, most of whom are marginalised in multiple ways, the Constitutional Court rulings are of no benefit.

\section{Discussion, conclusions, and policy recommendations}

This review has examined the three Constitutional Court decisions that have rejuvenated many customary forest users' hope for controlling their customary land. While the decisions are something in which the 'adat community' can surely relish, the process for recognition has been slow. In this review, we show that while the decisions are positive for the claims of customary users, many groups of forest users remain excluded. Specifically, communities making claims on land that has already been removed from State forestland, conservation forests, forests issued to companies by concessions, and land over which they already have management rights, as well as transmigrant communities, have been excluded. We also demonstrated that although the process for developing guidelines and issuing hutan adat claims has been a slow one, the MoEF has been aggressively gazetting State forests, which will present challenges for hutan adat claims in the future. In this brief discussion, we highlight some other issues that may arise in adat areas before covering some policy recommendations.

Adat means customary, not communal. Although often interpreted as such, it is erroneous to assume that customary means communal, and it cannot be equated with concepts of equality. Historically, Indonesia's access to natural resources has been managed by elites built on social contracts between rulers and subjects with varying results for the protection of forests (Thoms 2008; Henley 2007). This means that divergent interests are at stake and that priorities may serve to increase inequality and environmental degradation within hutan adat. Customary forest permits issued by the province of Central Kalimantan highlight some of the ways local users may choose to redefine ownership of land. In one case, the chief (damang) favoured issuing land permits for customary lands under individual ownership rather than communal ownership due to the lack of communal land titling regulations at the time. This effectively privatised formerly communal customary land and has been practiced both inside and outside forest areas by district authorities (Savitri 2013).

There remains considerable uncertainty about what communities will be able to do with their newly acquired statutory rights, even with the nine approved hutan adat areas. Issues have already arisen as local communities prepare to make their hutan adat claims. In one case in Central Kalimantan, an afforestation concession holder was approached by the local community to support their claim for hutan adat within the concession. Anticipating that the concession holder may not be overly enthusiastic to release land to the community, they offered a profit-sharing arrangement. According to their plan, the profit to be shared would be derived from the gold mine that they would establish in a formerly protected forest. Others have also raised this issue, which was particularly salient when there was a dispute as to whether or not hutan adat would still be included in State forests (see Meijaard 2015). We would be remiss to not provide some policy recommendations along with this review. The first is to sort out the details of what hutan adat means. This task, along with defining the 
mechanisms by which claims can be made, has been left to the MoEF, which we suggest should include more participation and oversight from civil society than has been practiced so far if not designated to an independent body. MoEF oversight is counterintuitive from the perspective that the Constitutional Court decisions asserted that the State has not sufficiently applied constitutional law. The application of the decisions remains tenuous. It is still currently within the power of the State to determine whether or not customary communities exist, which contrasts with peoples' right to self-determination as enshrined in the United Nations Charter and the International Covenant on Civil and Political Rights (ICCPR), which Indonesia ratified in 2006.

We urge that progress on culminating the diverse land use maps (known as the OneMap System) integrate hutan adat claims, other customary claims, and community land claims and contestations. The BRWA, working closely with AMAN, the JKPP, Forest Watch Indonesia (FWI), Konsorsium Pendukung Sistem Hutan Kerakyatan (KpSHK), and Sawit Watch (SW), has put considerable effort into mapping and preparing claims for hutan adat, but these efforts have yet to be formally integrated into national land use planning and operate in parallel with State procedures. Related to this, it is unclear how hutan adat are considered within the President's initiative to allocate 12.7 million hectares for social forestry (which includes industrial plantations and social forestry).

Second, the gap between perceptions among different units of government and community groups needs to be minimised. There continue to be divergent interpretations of whether or not a hutan adat is included in the forest zone. Even as communities mobilise to make their hutan adat claims, they do so with incomplete information and with understandings that may diverge significantly from the MoEF.

Third, settling land claims where third parties have current management and operational licences (i.e., 'legal' rights) requires that an arbitrator be established to deal with contestations pitted against customary rights that may or may not be acknowledged by the State. Since logging and conservation permits are issued by the MoEF, we suggest that the arbitrator be an independent body that can accommodate and process the claims in a timely manner. Settlements involving the collaboration of licence holders and hutan adat claimants should be explored wherever possible. Such settlements may involve less than full exploitation of the land under logging permits, for example, so that areas under hutan adat can be protected or the benefits from exploitation can be shared with the communities, according to specific cases.

Fourth, we argue that provinces and districts are equally accountable to the Constitution as the Government of Indonesia. Therefore, taking into account the same BAL and the same Constitution, districts should create a similar level of territorial categorisation as hutan adat for the groups that we have recognised as unable to benefit from the Constitutional Court rulings, as they are outside of State forestland. Some districts have already done this, and some have even done so in advance of the Constitutional Court rulings. Land tenure security should be a serious concern for land inhabited by transmigrants (which admittedly may conflict with customary land tenure) and customary claims on land that has been removed from State forestland and converted to general purpose land (usually to support industries such as mining and commercial plantations).

Fifth, the process of claiming hutan adat should be accompanied with the appropriate resources to assist the claimants to navigate the requirements. This would likely include providing assistance to develop maps based on customary usage and documentation of 
customary forest use regulations and proving customary usage in ways that will qualify claims for consideration. While BRWA is doing this within its resources, it is challenged to reach all potential claimants while other actors apply for management rights permits on the same lands.

Sixth, communities and subnational government officials must be made aware of the possibility for communities to claim hutan adat. In our experience, most community leaders we have talked with (by 2014) were not yet aware that the Constitutional Court decisions have even been made, let alone what the decisions could mean to them. As we discussed in this paper, hutan adat options are often not well communicated, even when gazetting forestland.

The Constitutional Court decisions were groundbreaking in the State's recognition of customary land claims. Although they pertain to forests, they may pave the way for customary claims on non-forestland also, thereby potentially benefiting communities in the situations we discuss in this paper. We remain cautiously optimistic that the Constitutional Court decisions have clarified the rights of customary land holders to gain statutory land tenure if our recommendations (and the calls of others) are taken seriously. If not, the decisions could spark momentary optimism among communities that could briefly ignite a fire that is easily be smothered in bureaucratic red tape, inadequate support to claimants, and political obstructions. This momentum could propel changes that broaden the recognition of marginalised communities' rights over State forests.

\section{Acknowledgments}

As stated in the introduction to the paper, the authors come from a range of institutions, and this paper is positioned as a policy review based on the social science research experience of each of the authors. We, therefore, wish to thank the various organisations that have afforded us these experiences. They include the Global Comparative Study on REDD+ by the Center for International Forestry Research (CIFOR) on which two of the authors worked, the World Agroforestry Center (ICRAF), the University of East Anglia, the Australian National University, the University of Twente, the Samdhana Institute, Leiden University, and the Faculty of Forestry at Universitas Gadjah Mada (UGM), specifically UGM's International Visiting Scholars' program, which enabled the collaboration required to polish the article. We also appreciate the valuable reviews and contributions to earlier versions of this article by Myrna Safitri, formerly of the Epistema Institute and HuMa, and Fitrian Ardiansyah, formerly of the Australian National University and Pelangi Indonesia. A final thanks to the highly expert and constructive anonymous reviewers who made several suggestions that greatly improved the quality of this paper. We are not aware of any conflict of interest associated with this contribution, and there is no significant financial support that influenced our findings. The authors were not paid directly for the production of this contribution. 


\section{References}

AMAN. 2013. "Aliansi Masyarakat Adat Nusantara." May. http://www.aman.or.id/2013/05/16/mahkamah-konstitusi-setujui-judicial-reviewterhadap-uu-kehutanan/.

Arnscheidt, J. 2009. "Debating” Nature Conservation: Policy, Law and Practice in Indonesia: A Discourse Analysis of History and Present. Leiden: Leiden University Press.

Bakker, Laurens, and Sandra Moniaga. 2010. "The Space between: Land Claims and the Law in Indonesia." Southeast Asian Journal of Social Science 38 (2). Brill: 187-203.

Barr, C. 2006. "Forest Administration and Forestry Sector Development prior to 1998." In Decentralization of Forest Administration in Indonesia: Implications for Forest Sustainability, Economic Development and Community Livelihoods, edited by B. Setiono, M. Moeliono, John F. McCarthy, A. Dermawan, I. A. P. Resosudarmo, and C. Barr. Bogor: Center for International Forestry Research.

Barr, C., A. Dermawan, J. McCarthy, M. Moeliono, and Iap Resosudarmo. 2006.

"Decentralization and Recentralization in Indonesia's Forestry Sector: Summary and Recommendations." In Decentralization of Forest Administration in Indonesia: Implications for Forest Sustainability, Economic Development and Community Livelihoods, edited by B. Setiono, M. Moeliono, John F. McCarthy, A. Dermawan, I. A. P. Resosudarmo, and C. Barr. Bogor: Center for International Forestry Research.

Bettinger, Keith, Micah Fisher, and Wendy Miles. 2014. "The Art of Contestation and Legitimacy: Environment, Customary Communities, and Activism in Indonesia." In Occupy the Earth: Global Environmental Movements, 195-224. Emerald Group Publishing Limited.

BRWA. 2016a. "Statistik Wilayah Adat." Badan Registrasi Wilayah Adat (BRWA). http://www.brwa.or.id/stats.

—. 2016b. "Pendaftaran Wilayah Adat Untuk Mewujudkan Pengakuan Wilayah Adat Di Indonesia." Badan Registrasi Wilayah Adat (BRWA). January 27. http://brwa.or.id/news/read/252.

Colchester, Marcus. 2002. "Indigenous Rights and the Collective Conscious." Anthropology Today 18 (1). [Wiley, Royal Anthropological Institute of Great Britain and Ireland]: 13.

- 2006. Justice in the Forest: Rural Livelihoods and Forest Law Enforcement. Vol. 3. Forest Perspectives. Bogor: CIFOR.

Colchester, Marcus, Norman Jiwan, Andiko, Martius Sirait, Asep Yunan Firdaus, A. Surambo, and Herbert Pane. 2006. Promised Land: Palm Oil and Land Acquisition in Indonesia - Implications for Local Communities and Indigenous Peoples. Bogor: Forest Peoples Programme, Perkumpulan Sawit Watch, HuMA and the World Agroforestry Centre.

Contreras-Hermosilla, Arnoldo, and Chip Fay. 2005. "Strengthening Forest Management in Indonesia through Land Tenure Reform: Issues and Framework for Action.” Forest Trends.

Direktorat Jenderal Planologi Kehutanan. 2014. "Strategi Pengembangan KPH Dan Perubahan Struktur Kehutanan Indonesia." Kementerian Lingkungan Hidup dan Kehutanan. 
Elmhirst, R. 2011. "Migrant Pathways to Resource Access in Lampung's Political Forest: Gender, Citizenship and Creative Conjugality." Geoforum 42. Elsevier: 173-83.

Fanani, Aubrey Kandelila. 2017. "Hutan Adat Yang Kembali Ke Pangkuan Masyarakat." Antara News, January 9.

Fearnside, Philip M. 1997. "Transmigration in Indonesia: Lessons from Its Environmental and Social Impacts." Environmental Management 21 (4). Springer-Verlag: 553-70.

FKKM and HUMA. 2012. "Hutan Kemasyarakatan (HKm)." InfoBrief Kehutanan Masyarakat. Jakarta: FKKM and HUMA.

Foresthints.news. 2017. "Customary Forest within Pulp Giant Concession Granted to Indigenous Group.” Foresthints.news. January 2.

http://www.foresthints.news/customary-forest-within-pulp-giant-concession-granted-toindigenous-group.

Fujiwara, Takahiro, S. A. Awang, W. T. Widayanti, R. M. Septiana, H. Bariatul, M. Rahmat, A. Suyanto, and N. Sato. 2011. "Overcoming Vulnerability of Privately Owned SmallScale Forest through Collective Management Unit Establishment: A Case Study of Gunung Kidul District, Yogyakarta in Indonesia." International Journal of Social Forestry 4 (2). ijsf.org: 95-120.

Gilbert, Jeremie. 2014. "Land Rights as Human Rights: The Case for a Specific Right to Land." SUR International Journal on Human Rights 10 (18). papers.ssrn.com: 115-36.

Henley, D. 2007. "Natural Resource Management: Historical Lessons from Indonesia." Human Ecology 36: 273-90.

Henley, D., and J. S. Davidson. 2007. "Introduction: Radical Conservatism - the Protean Politics of Adat." In The Revival of Tradition in Indonesian Politics, edited by S. Davidson and D. Henley. Abingdon: Routledge.

Indrarto, Giorgio Budi, Prayekti Murharjanti, Josi Khatarina, Irvan Pulungan, Feby Ivalerina, Justitia Rahman, Muhar Nala Prana, Ida Aju Pradnja Resosudarmo, and Efrian Muharrom. 2012. "The Context of REDD+ in Indonesia: Drivers, Agents and Institutions." Vol. Working Paper 92. Bogor: CIFOR.

http://www.cifor.org/publications/pdf_files/WPapers/WP92Resosudarmo.pdf.

Intarini, Dian Yusvita, Ida Aju Pradnja Resosudarmo, Mella Komalasari, Andini Desita Ekaputri, and Made Agustavia. 2014. "Ketapang Community Carbon Pools, Ketapang, West Kalimantan, Indonesia." In REDD+ on the Ground: A Global Case Book of Subnational Initiatives, edited by Erin O. Sills, Stibniati S. Atmadja, Claudio de Sassi, Amy E. Duchelle, Demetrius L. Kweka, Ida Aju Pradnja Resosudarmo, and William D. Sunderlin. Bogor: CIFOR.

IPAC. 2013. "Mesuji: Anatomy of an Indonesian Land Conflict." IPAC Report No 1. IPAC.

Kementerian Kehutanan. 2013. "Statistik Kehutanan Indonesia." Jakarta: Kementerian Kehutanan.

Kementerian Lingkungan Hidup dan Kehutanan. 2015. "Statistik Kementerian Lingkungan Hidup Dan Kehutanan 2014."

Komnas HAM. 2016. "National Inquiry on the Rights of Customary Law-Abiding Communities over Their Land in Forest Areas." Komnas HAM.

Kompas. 2015. "Rendah, Target 12,7 Juta Hektar Hutan Cari Solusi," January 19.

Li, Tania Murray. 2007. "Practices of Assemblage and Community Forest Management." Economy and Society 36 (2): 263-93.

- 2011. "Centering Labor in the Land Grab Debate." The Journal of Peasant Studies 38: 281-98.

Lund, Christian. 2010. “Approaching Development: An Opionated Review." Progress in Development Studies 10 (1): 19-34. . 2011. "Fragmented Sovereignty: Land Reform and Dispossession in Laos." The 
Journal of Peasant Studies 38 (4). Taylor \& Francis: 885-905.

Magdalena, and Rahayu Supriadi. 2014. "Masyarakat Sekitar Taman Nasional Dan Isu

Kepemilikan Hutan." In Hutan Untuk Rakyat, edited by Ismatul Hakim and Lukas R.

Wibowo. Yogyakarta: LKIS.

Maryudi, A. 2015a. "An Innovative Policy for Rural Development? Rethinking Barriers to

Rural Communities Earning Their Living from Forests in Indonesia." Jurnal Ilmu

Kehutanan. jurnal.ugm.ac.id. http://www.jurnal.ugm.ac.id/jikfkt/article/view/8575.

_ 2015b. "The Political Economy of Forestland-Use, the Timber Sector, and Forest Certification." In The Context of Natural Forest Management and FSC Certification in

Indonesia, edited by Ruslandi, 9-34. Bogor: Center for International Forestry Research.

Maryudi, A., Erlita R. Citraningtyas, Ris H. Purwanto, Ronggo Sadono, Priyono Suryanto,

Slamet Riyanto, and Bowo D. Siswoko. 2016. "The Emerging Power of Peasant

Farmers in the Tenurial Conflicts over the Uses of State Forestland in Central Java, Indonesia." Forest Policy and Economics 67: 70-75.

Maryudi, A., and M. Krott. 2012. "Local Struggle for Accessing State Forest Property in a

Montane Forest Village in Java, Indonesia." Journal of Sustainable Development in

Africa. search.proquest.com, 62-68.

Meijaard, Erik. 2015. "Tricky Tradeoffs between Indigenous Land Rights and

Deforestation." Jakarta Globe, December 25.

http://jakartaglobe.beritasatu.com/opinion/erik-meijaard-tricky-tradeoffs-indigenousland-rights-deforestation/.

Moeliono, M. 2002. “Adat and Globalization Living Apart Together." In The Commons in an Age of Globalisation, the Ninth Biennial Conference of the International Association for the Study of Common Property. Victoria Falls, Zimbabwe.

Moniaga, S. 1993. "Toward Community-Based Forestry and Recognition of Adat Property Rights in Outer Islands of Indonesia." In Legal Frameworks for Forest Management in Asia, edited by Jefferson Fox, 131-50. Honolulu: East-West Center.

—. 2007. "From Bumputera to Adat: A Long and Confusing Journey." In The Revival of Tradition in Indonesian Politics: The Deployment of Adat from Colonialism to Indigenism, edited by J. S. Davidson and D. Henley. London: Routledge.

Myers, Rodd. 2015. "Access in a Global Rattan Production Network: A Case Study of Rattan Originating from Central Sulawesi, Indonesia and Upgraded for Sale in International Markets." University of East Anglia.

Myers, Rodd, and Fitrian Ardiansyah. 2014. "Who Holds Power in Land-Use Decisions?" CIFOR Info Brief 100. Bogor: CIFOR.

Myers, Rodd, and Mumu Muhajir. 2015. "Searching for Justice: Rights vs 'benefits' in Bukit Baka Bukit Raya National Park, Indonesia." Conservation \& Society 13 (4): 370-81.

Myers, Rodd, Anna Sanders, Anne Larson, Ashwin Ravikumar, and Rut Dini Prasti H. 2016.

"Analyzing Multilevel Governance in Indonesia: Lessons for REDD+ through Land Use Change and Benefit Sharing in Central and West Kalimantan, Indonesia." 202. Bogor: CIFOR.

Neumann, Roderick. 1998. Imposing Wilderness: Struggles over Livelihood and Nature Preservation in Africa. Berkeley: University of California Press.

Pahlevi, Aseanty. 2015. "Nasib Pilu Tembawang Yang Mulai Tergerus Sawit Dan Tambang." Mongabay.co.id. March 30. http://www.mongabay.co.id/2015/03/30/nasibpilu-tembawang-yang-mulai-tergerus-sawit-dan-tambang/.

Peluso, Nancy Lee. 1992. Rich Forests, Poor People. Berkeley: University of California Press.

Peluso, Nancy Lee, Suraya Afiff, and Noer Fauzi Rachman. 2008. "Claiming the Grounds for Reform: Agrarian and Environmental Movements in Indonesia." Journal of Agrarian 
Change 8. Blackwell Publishing Ltd: 377-407.

Peluso, Nancy Lee, and Peter Vandergeest. 2001. "Genealogies of the Political Forest and Customary Rights in Indonesia, Malaysia, and Thailand." The Journal of Asian Studies 60 (3): 761-812.

Prabowo, D., A. Maryudi, Senawi, and M. A. Imron. 2017. "Conversion of Forests into Oil Palm Plantations in West Kalimantan, Indonesia: Insights from Actors' Power and Its Dynamics." Forest Policy and Economics 78: 32-39.

Rachman, Noer Fauzi, and Mia Siscawati. 2016. "Forestry Law, Masyarakat Adat and Struggles for Inclusive Citizenship in Indonesia." In Routledge Handbook of Asian Law, edited by C. Antons. New York: Routledge.

Royo, N., and A. Wells. 2012. "Community Based Forest Management in Indonesia: A Review of Current Practice and Regulatory Frameworks." In.

Safitri, Myrna Asnawati. 2010. "Forest Tenure in Indonesia : The Socio-Legal Challenges of Securing Communities' Rights.” 2010-12-15: Leiden University. https://openaccess.leidenuniv.nl/handle/1887/16242.

Sahide, Muhammad Alif K., and Lukas Giessen. 2015. "The Fragmented Land Use Administration in Indonesia--Analysing Bureaucratic Responsibilities Influencing Tropical Rainforest Transformation Systems." Land Use Policy 43. Elsevier: 96-110.

Savitri, Laksmi Adriani. 2013. "Land Control and Ideological Struggle: Competing Articulations of 'the Owner of Land."' Journal of Rural Indonesia 1 (1). ejournal.skpm.ipb.ac.id: $35-56$.

Setiawan, Eko N., A. Maryudi, Ris H. Purwanto, and Gabriel Lele. 2016. “Opposing Interests in the Legalization of Non-Procedural Forest Conversion to Oil Palm in Central Kalimantan, Indonesia." Land Use Policy 58 (December): 472-81.

Sikor, Thomas, and Christian Lund. 2009. "Access and Property: A Question of Power and Authority." Development and Change 40 (1). Wiley Online Library: 1-22.

Sikor, Thomas, and Johannes Stahl. 2011. "Introduction: The Rights-Based Agenda in International Forestry." In Forests and People, edited by Thomas Sikor and Johannes Stahl. London: Earthscan.

Sunderlin, William. 2011. "The Global Forest Tenure Transition: Background, Substance and Prospects." In Forests and People, edited by Thomas Sikor and Johannes Stahl. London: Earthscan.

Taylor, Jean Gelman. 2003. Indonesia: Peoples and History. New Haven: Yale University Press.

The Samdhana Institute, and Rights and Resources. 2016. "Land Rights and Conservation in Indonesia."

Thoms, Christopher A. 2008. "Community Control of Resources and the Challenge of Improving Local Livelihoods: A Critical Examination of Community Forestry in Nepal." Geoforum; Journal of Physical, Human, and Regional Geosciences 39 (3): $1452-65$.

Watts, M. 2004. "Violent Environments: Petroleum Conflict and the Political Ecology of Rule in the Niger Delta, Nigeria." In Liberation Ecologies: Environment, Development, Social Movements, edited by R. Peet and M. Watts. London: Routledge.

Watts, M., and Hans G. Bohle. 1993. "Hunger, Famine and the Space of Vulnerability." GeoJournal 30 (2). Springer: 117-25.

Wright, Glen. 2011. "Indigenous People and Customary Land Ownership under Domestic REDD+ Frameworks: A Case Study of Indonesia." Law and Development Journal 7/2. 